\title{
Stage Ois Renal Pelvis Cancer AJCC v8
}

National Cancer Institute

\section{Source}

National Cancer Institute. Stage Ois Renal Pelvis Cancer A/CC v8. NCI Thesaurus. Code C140362.

Stage Ois includes: T is, NO, MO. T is: Carcinoma in situ. N0: No regional lymph node metastasis. M0: No distant metastasis. (AJCC 8th ed.) 